\title{
Search for Facility Management's KPIs to manage the hospitals infrastructure in Colombia
}

\author{
M. Madroñal ${ }^{1,2, \psi}$, B.J. Galeano ${ }^{1}$, N.J. Escobar ${ }^{1}$ \\ ${ }^{1}$ Grupo de Investigaciones en Bioingeniería Clínica, GIBIOING, Universidad Pontificia Bolivariana - \\ Medellín, Colombia \\ ${ }^{2}$ Grupo de Gestión Tecnológica e Innovación, GTI, Universidad Pontificia Bolivariana - \\ Medellín, Colombia
}

\begin{abstract}
Nowadays, hospital physical asset management is gaining importance due to the size of its buildings, social relevance, operational and maintenance costs. The purpose of this document is to identify the Key Performance Indicators (KPIs) and categorize them into specific aspects of measurement of infrastructure performance. The lack of an adequate classification of performance indicators prevents the widespread use of performance measures for Facility Management (FM) in the health sector. This article shows a brief review of the state of art of FM KPIs based on a bibliographic search, taking into account international authors and reviewing their approaches and categorizations. The authors of this paper present a summary of the categorization and approach of hospital infrastructure management based on the documents examined, which may offer a more practical use for FM professionals in the healthcare sector. Facility Managers have to tackle too much data, which hinders to carry out a deeper analysis of the key performance indicators in future researches, attempting to generate indicators that match with the organization objectives and that lead to a more intelligent and efficient health infrastructure management.
\end{abstract}

Keywords - Asset Management, Facility Management, Infrastructure, Hospitales, KPI.

\section{BÚSQUEDA DE KPI de Facility MANAGEMENT PARA ADMINISTRAR LA INFRAESTRUCTURA HOSPITALARIA EN COLOMBIA}

Resumen-Hoy en día, la gestión de activos físicos hospitalarios está ganando importancia debido al tamaño de sus edificios, relevancia social, costos operacionales y de mantenimiento. El propósito de este documento es identificar los Indicadores de Desempeño Clave (KPIs) y categorizarlos en aspectos específicos de la medición del desempeño de la infraestructura. La falta de una adecuada clasificación de los indicadores de desempeño impide el uso generalizado de medidas de desempeño para la Gestión de Instalaciones (FM) en el sector de la salud. Este artículo presenta una breve revisión del estado del arte de los KPI FM basados en una búsqueda bibliográfica, teniendo en cuenta a los autores internacionales y revisando sus enfoques y categorizaciones. Los autores de este trabajo presentan un resumen de la categorización y enfoque de la gestión de la infraestructura hospitalaria a partir de los documentos examinados, lo que puede ofrecer un uso más práctico para los profesionales de FM en el sector de la salud. Los gestores de instalaciones tienen que abordar demasiados datos, lo que dificulta un análisis más profundo de los indicadores clave de rendimiento en futuras investigaciones, tratando de generar indicadores que coincidan con los objetivos de la organización y que conduzcan a una gestión de la infraestructura de salud más inteligente y eficiente.

Palabras clave—Gestión de Activos, Facility Management, Infraestructura, Hospitales, KPI.

\% Author's mailing address: manuel.madronal@upb.edu.co

DOI: https://doi.org/10.24050/19099762.n20.2017.1068 


\section{Busca dos Indicadores Chave de Desempenho, KPIs, da Gestão de INSTALAÇÕES PARA GERENCIAR A INFRA-ESTRUTURA DOS HOSPITAIS NA COLÔMBIA}

Resumo-Hoje em dia, a gestão de ativos físicos hospitalários está a ganhar importância devido ao tamanho de seus prédios, sua relevância social, os custos operacionais e de manutenção. O propósito deste documento é identificar os Indicadores Chave de Desempenho (KPIs, em inglês) e categorizá-los em aspectos específicos da medição do desempenho da infra-estrutura. A falta de uma adequada classificação dos indicadores de desempenho impede o uso generalizado de medidas de desempenho para a Gestão de Instalações (FM, em inglês) no sector da saúde. Este artigo apresenta uma breve revisão do estado da arte dos KPI de FM baseados numa procura bibliográfica, tendo em conta aos autores internacionais e revisando seus enfoques e categorizações. Os autores deste trabalho apresentam um resumo da categorização e enfoque da gestão da infra-estrutura hospitalaria a partir dos documentos examinados, o que pode oferecer um uso mais prático para os profissionais da Gestão de Instalações - FM no sector da saúde. Os gestores de instalações têm que abordar bastante dados, o que dificulta uma análise mais profunda dos indicadores chave de rendimento em futuras investigações, tentando gerar indicadores que coincidam com os objetivos da organização e que conduzam a uma gestão da infra-estrutura de saúde mais inteligente e eficiente.

Palavras-chave - Gestão de Ativos; Gestão de Instalações; Infra-estrutura; Hospitais; KPI..

\section{INTRODUCTION}

$\mathrm{I}^{\mathrm{n}}$ the last decades in Latin America, health systems have been reformed with respect to the World Bank guidelines based on neoliberal ideals, causing substantial changes in the administration of resources and attention to the population. Governments are prone to uphold the principles of equity, efficiency, utility, quality and user satisfaction, though, at the same time the health service is decentralized, privatized and delimited [1]. The Colombian Health System comprises the financing, the administration of the resources, the services regulation and the provision of the health services. On one hand, the administration of the system is delegated to the Health Promoting Entities (HPE) both in the public and in private sector, being in charge of the affiliation and fee collection process. On the other hand, Health Service Delivery Entities (HSP) are those organizations that provide care to users of all levels, performing health activities by their health professionals on the services contracted by the HPE and paid off after a complex billing, audit and agreement statement process [2].

In economic terms, the physical asset of a hospital is one of the most important investment for a HSP, therefore, the disciplines of engineering and architecture are fundamental to reform and transform the organizational structure, and thus help the recovery of the patients in the organizational climate and the community in general. The hospital infrastructure must represent the mission, values and principles of the organization, and it must be built, maintained and operated intentionally to achieve organizational objectives considering the maintenance, the investments and the internal structure management of the building [3].
Physical Asset Management is an underway concept, there is not yet an established definition, even less in the hospital sector. The use of this term for maintenance managers in the USA has been used to gain greater credibility in their activities. As maintenance was understood as a work without importance, the term "asset management" seems to be more appealing and professional, even though maintenance is a fundamental component in the asset management policy of the company.

The Asset Management discipline has evolved developing good practice manuals, specifications and new international standards such as ISO 55000: 2014 [4], which has been published by the International Standard Organization (ISO) from PAS 55 specification of the British Standard Institute (BSI). This standard provides an overview of asset management, its principles and terminology, and the expected benefits in its adoption.

Amendola states [5] that ISO 55000 could be applied to all types of assets and all sorts and sizes of organizations, such as the IPS in Colombia. This standard allows the organization to operate in line with the requirements of the business, maintain its productive capacity or service, avoiding losses and increasing efficiency in its operations.

The authors of this paper, aligned to the doctoral research of the main author, have considered FM as the appropriate discipline to manage the hospital infrastructure in Colombia.

Facility Management is defined as "A management model of real estate asset of companies that aim to adapt them permanently to the organization and the companies personnel at the lowest possible cost, by integrating all the management responsibilities on those resources", according to the Spanish Society of 
Facility Management (SEFM) and International Facility Management Association (IFMA).

This discipline has been focused on the physical asset management (infrastructure), which becomes more complex with the past of days and contains more technology, sparking a major competitiveness, cost, demand, health expectations, consumers' safety and welfare, in addition to the environment. Considering that the institutions add new responsibilities and challenges in their work environments to the social purpose of the organization [6], the FM has a very wide scope of work, also aligned with the Strategic Plan of the Organization [7]. Alexander [8] determined that " the FM role is to meet the business challenges that confront the organization that it is supporting, for reaching the optimum balance between people, physical assets and technology". Additionally, other authors citing Alexander [8] concluded that a successful FM development conduce to achieve the goals of an organization with "the best combination of efficiency and cost".

Thus, Shohet and Lavy [9] point out that the arrival of FM and other disciplines to IPS has been growing internationally, along with its impact on the quality and effectiveness of health services. Gelnay [10] sees FM in the health sector as a key element for the success of the delivery of health services. However, he noted that in most of the hospitals studied in his research, the Facility Manager was not involved in the stages of planning, design and cost analysis. Other researchers have also emphasized that Facility Managers should be involved in decision-making processes, becoming especially important in IPS. In the same line, Gallagher [11] has reviewed the main areas in which the FM in Health has been implemented, such as the NHS in the United Kingdom, including in these areas strategic planning, customer service, market testing, benchmarking, environmental management and staff development. These studies have examined the development of the FM profession in the NHS, finding out that the NHS Trust tends to integrate noncore services (for example, risk management, energy efficiency, cleanliness, safety) under the umbrella of an FM department. Another point of study was the effect of the following five factors [12] on the users' satisfaction in the health services:

(1) Level of communication between staff and patient;

(2) Competence, skills and service providers' experience;

(3) Quality of infrastructure;

(4) Positive staff reaction to patients;
Amaratunga states [8] that all these sources reinforce the understanding that the effectiveness of health services will improve with the growth and development of the FM profession. Consequently, this will lead to a change in the position of the FM in the IPS and it will therefore become the central axis of the organization, supporting the decision-making system and its functioning processes.

According to Loosemore [22], the use of KPIs in an FM environment can generate many advantages. For example, they can focus managerial efforts on relatively important performance areas. They can be incorporated into the contract specifications, and the documentation used in the selection of the contractors, communicating clear expectations of the desired results, and how they will be monitored and controlled. Management control and accountability are also reinforced by early intervention and possible corrective measures in response to more visible variations in performance. As Peter Drucker holds: "It is not possible to manage what you can not control and you can not control what you can not measure."

Cable and Davis [13] argue that an unsuitable management of KPIs could result in an inadequate infrastructure to support the HSP operation, excessive infrastructure that does not contribute to the organization's mission, cost inefficiencies, inadequacy and unavailability of infrastructure for future needs. Hence, an appropriate FM approach can provide the necessary support to the organization's mission, realization of future facility requirements, greater cost efficiency and the ability to anticipate the results of current management decisions.

Amaratunga et al. [14] hold that the performance measurement is vital for an organization as it provides a needed management direction. Performance measurement expands the opportunities to review past and present performance and to come up with future strategies for the successful operation of the organization and the achievement of its strategic goals [15].

In this respect, KPIs back up Facility Managers to evaluate the effectiveness of various functions and important processes to achieve the organization's goals. These KPIs are intrinsically linked to the organization's strategic objectives and are used by the Facility Managers to assess whether they meet the goals set out in the organizational objectives. The information provided by KPIs could also facilitate hospital administrators manage the budget risk and develop budget mitigation strategies. According to Boussabaine et al. [17], the use of such parameters (KPIs) will allow maintenance experts to initiate more precise and specific budget predictions regarding the required maintenance established for the infrastructure. Following the analysis of several KPIs by Cooper and Jones 
[18], different categories such as physical performance, social performance, environmental performance and economic performance should be taken into account.

Shohet \& Lavy [4] indicate that a group of Australian researchers (Pullen et al., 2000) developed a tool that can contribute to the complicated management of hospital infrastructure, identifying that the main factors affecting hospital performance are hospital size, occupation, asset value, income and operating costs. These factors led to the development of seven KPIs, four of which include hospital incomes. It seems that this spectrum of indicators is more aligned to the Colombian case, since they are more suitable for the private sector than for public hospitals.

The purpose of this study is to identify, through a bibliographic search, the KPIs for the hospital infrastructure management that are compatible with Asset Management through FM discipline, so that a Facility Manager can assess the contribution to the hospital infrastructure management and the physical asset management of the IPS in Colombia. The articles and documents selected in the search will be analyzed, focusing on the number of KPIs selected by each author to manage an infrastructure, and also the classification of KPIs into different categories, taking into account the type of infrastructure (hospital). It is also worth noting the nationalities and institutions the most relevant researchers on KPIs come from, especially in the health sector.

\section{Methodology}

To fulfill the objectives described above, this article presents a procedure that involves a brief review of the state of the KPIs to manage (hospital) infrastructure through FM discipline. Initially, the method has been based on a bibliographic search in digital databases, such as Scopus, Web of Science and GoogleScholar. Then, the appropriate terms have been selected taking into account the most recent and relevant references related to the subject of study. This process allows to collect information on science and technology, selecting and analyzing it, in order to make decisions that identify which countries have been investigated, what authors have written about these themes and in which areas they have worked the selected topics.

The data collected through the bibliographic search include articles in journals, conference proceedings and presentations on key performance indicators. Each document was studied considering the indicators and whether these were related to the methods of performance evaluation. The analysis of each document includes the amount of KPIs, as well as its categorization depending on each author, the focus of the study and the sector for which the study was done.
In line with the management of the infrastructure, the authors present a different categorization and approach regarding each document studied, and although they do not offer a generalized view of the KPIs used in FM discipline, they can be adopted by the professionals of the hospital sector in Colombia.

After reading and analyzing the representative documentation for the study, the authors proceeded to make comparative tables that indicated the number of KPIs found in each document, and the number of categories. In this way, the authors carried out a benchmarking considering nationalities, approaches and different references, among the documents collected.

It is worth mentioning the need to seek an international standard that addresses the use of KPIs, in order to analyze these indicators, and if they are related to the performance categories of the obtained results.

This study carries out an average of the bibliographic search both in the number of KPIs and in the number of categories used by the authors of the search. This average should be compared with an international standard to identify if the studies developed in the last years are related to internationally valid regulations created by a European committee. The aim is that this research and its results can support the work done by the Facility Managers in Colombia, who do not yet have the means to carry out this type of comparative analysis.

Lastly, this paper shows some conclusions that can be useful for those interested in the hospital infrastructure management through FM discipline, detailing the future studies that this line of research will carried out.

Assimilating the above by Cable and Davis [13], they claim that a set of KPIs must be identified and tracked over a period of time so that it can be compared to a baseline in order to examine improvements or deterioration.

\section{RESUlTS}

The different types of existing measures, the types of data and information that this paper takes into consideration are called metrics. The exact terminology used is not important, though it is essential that we understand the difference between data, information and knowledge. On the one hand, the authors draw on measurements that are only data, consisting of a value for a defined unit of measure and a date / time stamp; variables such as cost, size, temperature, state and a range of conditions yes/no. On the other hand, we have the indicators, which are a sum of measurements on a single subject, for example the number of work orders completed in a concrete period, although, the indicators 
do not provide any different vision of the magnitude, which is the lowest level of information. Finally, we have the Key Performance Indicators (KPIs) that use a simple mathematical calculation, and provide significant information to the management of the organization as long as they are adequately treated. KPIs usually measure the effect of the organization objectives or goals through a scale of values. These values can be classified as: unacceptable, acceptable or desired.

The authors set different search equations in searchers such as Scopus, Web of Science and Google Scholar throughout the bibliographic search, trying to identify the studies based on developments, evaluations, categorizations and investigations on KPIs. However, these documents should be related to the physical asset management, focusing on the infrastructure, namely in the FM discipline, being the most suitable those papers regarding the health sector.

In the study, the authors have reviewed the summaries of up to 50 documents related to the different equations made in the different bibliographic search engines, in order to confirm the following requirements: state the different KPIs and / or state the different categories in which they classify the KPIs.

Within the first 50 documents, the following 20 articles have been taken into account: [20], [21], [22], [23], [24], [25], [26], [27], [28], [29], [30], [31], [32], [33], [34], [35], [36], [37], [38], [39]. All of these articles meet the requirements, since they indicate a number of KPIs that can be used to manage the infrastructure, and most of them also display different categorizations.

During the search, an international standard came out, the European standard EN 15341: 2007 [19], drew up by the European Technical Committee CEN / TC-319 and published by AENOR in Spain in 2008. CEN / TC-319 is responsible for standardization in the field of maintenance, as regards generic standards of general application. This research group made use of this standard to check whether the studies carried out in the last decade follow the same track, with respect to the number of KPIs and the number of categories. The EN 15341: 2007 standard says: "This standard describes a system that manages KPIs addressed to measure maintenance performance, with the aim of evaluating and improving efficiency and effectiveness that lead to achieve excellence in the Technical Assets Maintenance "[19].

Table 1 displays the results found in the analysis of the 20 articles. The authors state that between 2 and 97 KPIs can be used to manage the infrastructure through FM.
Table 1. Results of Analysis of Found Articles

\begin{tabular}{cccccc}
\hline Document & $\begin{array}{c}\mathbf{N}^{\mathbf{0}} \\
\text { Categories }\end{array}$ & $\begin{array}{c}\mathbf{N}^{\mathbf{0}} \text { of } \\
\text { KPI }\end{array}$ & Document & $\begin{array}{c}\mathbf{N}^{\mathbf{0}} \\
\text { Categories }\end{array}$ & $\begin{array}{c}\mathbf{N}^{\mathbf{0}} \text { of } \\
\text { KPI }\end{array}$ \\
\hline$[20]$ & 4 & 10 & {$[30]$} & 7 & 26 \\
{$[21]$} & - & 2 & {$[31]$} & 4 & 39 \\
{$[22]$} & 3 & 8 & {$[32]$} & 3 & 6 \\
{$[23]$} & 8 & 23 & {$[33]$} & 4 & 5 \\
{$[24]$} & 4 & 35 & {$[34]$} & - & 20 \\
{$[25]$} & 2 & 7 & {$[35]$} & 3 & 13 \\
{$[26]$} & 4 & 35 & {$[36]$} & 4 & 22 \\
{$[27]$} & 8 & 97 & {$[37]$} & 2 & 18 \\
{$[28]$} & 4 & 11 & {$[38]$} & 4 & 4 \\
{$[29]$} & 4 & 7 & {$[39]$} & 5 & 48 \\
\hline
\end{tabular}

However, concerning the number of categories in the classification of KPIs, authors use from 0 (meaning that is not categorized) up to 8 different types of categories to distinguish them, or to separate the different areas of the organization, and hence have a total control over the physical assets.

During the analysis of the resulting articles, it has been taken into account that the articles come from authors, institutions and organizations from countries with a high economic and social development. Table 2 shows this group of countries.

Table 2. Countries Involved in the Found Articles

\begin{tabular}{ccc}
\hline & Countries & \\
\hline USA & Israel & UK \\
Australia & Korea & Honk Kong \\
Canada & China & Germany \\
\hline
\end{tabular}

Of particular importance is that UNE-15341: 2007 presents 51 different KPIs classified in three groups, which are the basis to attain operational excellence. Thus, comparing this standard (both in number of KPIs and number of categories) with the average of the resulting articles, we can detect that the number of categories is considerably similar. However, the number of KPIs in the standard is almost the double than in the average of the resulting articles.

Table 3. Comparison between the Study Avarage and the EN-15341 Standard

\begin{tabular}{ccc}
\hline & Study Avarage & EN-15341 \\
\hline $\mathbf{N}^{0}$ Categories & 3,65 & 3 \\
$\mathbf{N}^{\mathbf{0}}$ of KPI & 21,8 & 51 \\
\hline
\end{tabular}

\section{Discussion}

Reviewing the data of the resulting articles, it is worth pointing out that Igal Shohet and Sarel Lavy, from the Technion Institute (Israel) and the University of Texas A \& M (USA), respectively, have been conducting research since 2003 on KPIs, FM and performance management 
in the hospital and educational sectors. Their studies maintain an average of 4 categories for the KPIs and an average of 13 KPIs compiled to measure the performance management of an organization's infrastructure (primarily in the healthcare sector).

Slater et al., cited in Lavy et al. [31], state that the appropriate number of KPIs should be maintained between a minimum of 7 and a maximum of 12 for a complete assessment of the performance of an infrastructure. Thus, the studies of Shohet and Lavy approach the assertion of Slater et al., and can be found within the range of KPIs and categories handled by the EN-15341 standard.

Given these points, it is necessary to carry out a detailed research of the KPIs that are within the set of basic attributes, that are more appropriate for FM in the Colombian healthcare sector, and that are also aligned with some international standards

\section{Conclusion}

The classification of KPIs for FM will be the basis to consider future research that can be performed after this study, taking into account the requirements of national and international standards in the management of hospital infrastructure in Colombia.

The indicators found in this study do not represent the complete list of performance indicators in the bibliographic search. The authors located points in common to carry out the performance measurement in a holistic way, giving rise to overlapping categories in the sector of study.

The authors understand that due to the broad spectrum of KPIs and the inadequate use of the categories, it is necessary to conduct a selective search and a better classification of the indicators. This would therefore benefit the performance measurement and would provide a better perspective to the studies.

It should be noted that there are other authors who have compiled different numbers of KPIs developed for different sectors and that all are fully reliable in their respective case studies.

Future research will focus on the need to develop a more effective and efficient set of KPIs in FM for performance assessment, focusing on the private Colombian health model.

\section{ACKNOWLEDGMenT}

We are immensely grateful to Mr. Jesús Vallejo for his revision and translation of this paper, and his comments on an earlier version of the manuscript, although any errors are our own and should not tarnish the reputations of this esteemed person.

\section{REFERENCES}

[1]. Homedes N., Ugalde A., Forns J.R. The World Bank, pharmaceutical policies, and health reforms in Latin America. International Journal of Health Services, 35, 691-717. 2005.

[2]. Riveros-Pérez E., Amado-González L.N. Health Care System in Colombia: funding based on social security or on taxes? Rev. Gerenc. Polit. Salud, Bogotá. 11(23), 111-120, julio-diciembre de 2012.

[3]. Negrotti A. Ponencia VII Congreso Mundial de Mantenimiento y Gestión de Activos: Curso Fundamentos para el Mantenimiento de Edificios Industriales y Corporativos. Facility Management (FM). 2015

[4]. ISO 55000:2014, Asset management -- Overview, principles and terminology, International Standard Organization. 2014.

[5]. Amendola L. Gestión integral del Mantenimiento de Activos como Estrategia de Negocios: (Assessment, PAS 55-ISO 55000). Mantenimiento: ingeniería industrial y de edificios, 267, 12-19. 2013.

[6]. Feingold V. Chapter Origen de la disciplina of Book "El libro del Facility Management", 13-19. SLFM, Argentina, 2012.

[7]. Feingold V. Chapter Real Estate Planning of Book "El libro del Facility Management”, 92-123. SLFM, Argentina, 2012.

[8]. Alexander K. Facilities Management: Theory and Practice, Spon Press, London. Cited by Amaratunga, D. and Baldry, D. (2002a), "Balanced scorecard: a universal solution to facilities management?", in Alexander, K. (Ed.), Proceedings of the Euro FM Research Symposium in Facilities Management, The University of Salford, Salford. 1996.

[9]. Shonet I.M., Lavy S. Healthcare facilities management: state of the art review, Facilities, 22(7/8), 210 - 220, 2004.

[10]. Gelnay B. Facility management and the design of Victoria Public Hospitals. Proceedings of the CIB Working Commission 70: Facilities Management and Maintenance Global Symposium, Glasgow, 525-45, 2002.

[11]. Gallagher M. Evolution of Facilities Management in the Health Care Sector, Construction Paper No. 86, The Chartered Institute of Building, Ascot, 1-8, 1998.

[12]. Andaleeb S.S. Determinants of customer satisfaction with hospitals: a managerial model, International Journal of Health Care Quality Assurance, 1(6), 181-7, 1998.

[13]. Cable J.H., Davis J.S. Key Performance Indicators for Federal Facilities Portfolios, Federal Facilities Council Technical Report 147, National Academies Press, Washington, D.C., USA, 2004,

[14]. Amaratunga D., Baldry D., Sarshar M. Assessment of facilities management performance, what next? Facilities, 18(1/2), 66-75, 2000 b.

[15]. Lebas M.J. Performance measurement and performance management. International Journal of Production Economics, 41(1-3), 23-35, 1995.

[16]. Reh J.F. Understanding Key Performance Indicators or KPI. Consulted in November 20, 2016 in: https://www.thebalance.com/ keyperformanceindicators 2275156 
[17]. Boussabaine H., Sliteen S., Catarina O. The impact of hospital bed use on healthcare facilities operational costs: The French perspective. Facilities, 30(1/2), 40-55, 2012.

[18]. Cooper J., Jones K. Routine maintenance and sustainability of existing social housing. Proceedings "CIB W070 Conference in Facilities Management". Heriot Watt University, Edinburgh. pp. 361-368, 2007.

[19]. BS-EN 15341:2007 Maintenance. Maintenance key performance indicators. British Standard Institution, 2007.

[20]. Lavy S. A literature review on measuring building performance by using key performance indicators. In AEI 2011: Building integration solutions, pp. 406-417, 2011.

[21]. Shohet I.M. Building evaluation methodology for setting maintenance priorities in hospital buildings. Construction Management and Economics, 21(7), 681-692, 2003.

[22]. Loosemore M., Hsin Y.Y. Customer-focused benchmarking for facilities management. Facilities, 19(13/14), 464-476, 2001.

[23]. Hinks, J., McNay P. The creation of a management-by-variance tool for facilities management performance assessment. Facilities, 17(1/2), 31-53, 1999.

[24]. Lavy S., Garcia J.A., Dixit M.K. Establishment of KPIs for facility performance measurement: review of literature. Facilities, 28(9/10), 440-464, 2010.

[25]. Gelnay B. Facility management and the design of Victoria Public Hospitals. In Proceedings of the CIB Working Commission, 70, 525-545, 2002.

[26]. Augenbroe G., Park C.S. Quantification methods of technical building performance. Building Research \& Information, 33(2), 159-172, 2005.

[27]. Ho D.C., Chan E.H., Wong N.Y., Chan M.W. Significant metrics for facilities management benchmarking in the Asia Pacific region. Facilities, 18(13/14), 545-556, 2000.

[28]. Shohet I.M. Key performance indicators for strategic healthcare facilities maintenance. Journal of Construction Engineering and Management, 132(4), 345-352, 2006.

[29]. Shohet I.M. Key performance indicators for maintenance of health-care facilities. Facilities, 21(1/2), 5-12, 2003.

[30]. Weber A., Thomas R. Key Performance Indicators - Measuring and Managing the Maintenance Function. Ivara Corporation, 2005.

[31]. Lavy S., Garcia J.A., Dixit M.K. KPIs for facility's performance assessment, Part I: identification and categorization of core indicators. Facilities, 32(5/6), 256-274, 2014.

[32]. Lavy S., Garcia J.A., Dixit M.K. KPIs for facility's performance assessment, Part II: identification of variables and deriving expressions for core indicators. Facilities, 32(5/6), 275-294, 2014.

[33]. Lavy S., Garcia J.A., Scinto P., Dixit M.K. Key performance indicators for facility performance assessment: simulation of core indicators. Construction Management and Economics, 32(12), 1183-1204, 2014.

[34]. Kavrakov D. Performance Management in Facility Management. Top Key Performance Indicators in FM. Insight, An EuroFM Publication, Issue 32, www.eurofm.org, 2015

[35]. Scholz S., Ngoli B., Flessa S. Rapid assessment of infrastructure of primary health care facilities-a relevant instrument for health care systems management. BMC health services research, 15(1), 183. 2015.
[36]. Coronel P., Evans A. Conference: AAPPA Conference, September 1999.

[37]. Pati D., Park C. S., Augenbroe G. Facility maintenance performance perspective to target strategic organizational objectives. Journal of Performance of Constructed Facilities, 24(2), 180-187, 2009.

[38]. Shohet I.M., Lavy-Leibovich S., Bar-On D. Integrated maintenance monitoring of hospital buildings. Construction Management \& Economics, 21(2), 219-228, 2003.

[39]. Yuan J., Zeng A.Y., Skibniewski M.J., Li Q. Selection of performance objectives and key performance indicators in public-private partnership projects to achieve value for money. Construction Management and Economics, 27(3), 253-270, 2009. 